\title{
ORGANIZATIONAL LEARNING IN PRACTICE-BASED STUDIES APPROACH: REVIEW OF SCIENTIFIC PRODUCTION
}

\author{
DANIELA G. DURANTE ${ }^{1}$ \\ (iD) https://orcid.org/0000-0001-9353-0905 \\ FABIANA R. VELOSO 2 \\ (iD) https://orcid.org/0000-0003-1731-2652 \\ DIEGO Q. MACHADO ${ }^{1}$ \\ (iD) https://orcid.org/0000-0002-3570-8864 \\ AUGUSTO C. A. CABRAL ${ }^{1}$ \\ (iD) https://orcid.org/0000-0001-8248-4886 \\ SANDRA M. SANTOS ${ }^{1}$ \\ (iD) https://orcid.org/0000-0002-8515-9146
}

To cite this paper: Durante, D. G., Veloso, F. R., Machado, D. Q., Cabral, A. C. A., \& Santos, S. M. (2019). Organizational learning in practice-based studies approach: Review of scientific production. Revista de Administração Mackenzie, 20(2). doi:10.1590/1678-6971/eRAMG190131

Submission: Aug. 2, 2018. Acceptance: Sept. 25, 2018.

\footnotetext{
1 Universidade Federal do Ceará (UFC), Fortaleza, CE, Brazil.

2 Universidade Estadual do Oeste do Paraná (Unioeste), Toledo, PR, Brazil.
}

\section{(cc) BY




\section{ABSTRACT}

Purpose: To review the scientific production on organizational learning, which made use of the practice-based studies approach, concerning the production evolution, the author's profile, methodological characteristics, and correlated themes.

Originality/value: Organizational learning presents gaps regarding contributions from other areas, such as Sociology. Practice Based Studies (PBS) have the sociological bias and the social space as a locus of learning processes and knowledge generation. No studies have been identified that review the national scientific production on organizational learning in the PBS context, reinforcing the potential contributions of this work. Design/methodology/approach: The research covered the papers available in Spell's database and in Capes Journals Portal, published until 2017, 42 in total. Those were systematically reviewed in a qualitative approach. Ucinet 6 and NetDraw software were also used in the analysis.

Findings: The publications are recent and focus on journals of national and international impact. The authorship is under responsibility of small groups, evidencing a partnership among the authors. The number of theoretical papers and the relevance of their contributions are significant. As for the empirical studies, there is a predominance of case study and interview. As to the themes, topics relevant to the PBS theoretical-methodological proposal are discussed. It was concluded that PBS, by taking the practices inserted in the context of organizations as a locus of learning study, reveal a potential to fill gaps in the traditional organizational learning perspective.

\section{KEYWORDS}

Organizational learning. Sociological perspective. Practice-based studies. Systematic review. Epistemology. 


\section{INTRODUCTION}

The discussion about learning in organizations is recurrent in the field of organizational studies. The theme has already been explored through diverse ontological and epistemological approaches, which are reflected in a multi-paradigmatic and complex field. Despite the diversity of perspectives, the theme was developed based on the essentially utilitarian view and the instrumental rationality, whose focus on learning is aimed at stimulating change, innovation and strategic utility, namely at the search for better performance (Antonello \& Godoy, 2010, Bertolin, Zwick, \& Brito, 2013, Bispo \& Godoy, 2012, Easterby-Smith \& Araujo, 2001).

On that account, the theme presents gaps in the contributions of other areas, such as Sociology, Anthropology, History, and Political Science (Antonello \& Godoy, 2009; Bispo, 2013). After reviewing the main Brazilian production on the subject, Antonello and Godoy (2009, p. 276) underline the need to carry out studies with a "broad base of knowledge disciplines, aiming at transdisciplinarity" by the contributions that different areas can provide to understand the procedural nature of social phenomena, such as learning in organizations.

It is at this point that one can see the potential of Practice-Based Studies (PBS) to contribute to knowledge advancement about learning in organizations. With the sociological bias, PBS have social space as a locus of learning processes and the generation of knowledge, and they use practices to understand social and organizational phenomena. That leads to knowledge as a collective construction, produced, reproduced and modified through social practices (Gherardi \& Nicolini, 2001; Gherardi \& Strati, 2014; Reckwitz, 2002). PBS compose an approach that returns to social studies in the practice turn movement, initiated in the area of Administration, in 1998, during a symposium of the Academy of Management, proposed by Davide Nicolini and Dvora Yanow (Bispo, 2013). It is a recent approach, especially in the Brazilian context.

It is noteworthy that six Brazilian production reviews on organizational learning were made available in the last decade. Antonello and Godoy (2009) explored the formative discourses of the organizational learning field that used the method called metatriangulation, from 2001-2005. Macedo et al. (2011) conducted a bibliometric study on managerial learning from 1996-2008. Bispo and Mello (2012) carried out a survey about the production on learning, at group and organizational levels, from 2000-2011. 
Faqueti, Alves, and Steil (2016) focused the review on the relationship between organizational learning and the academic libraries context, from 2005-2015. Oliva and Shinyashiki (2016) reviewed the production that deals specifically with validation of organizational learning scales, from 1990-2015. Finally, Carrasco and Silva (2017) analyzed the production on informal learning in the work context until 2016.

In regard to the practice-based studies, a general analysis of the Brazilian production was conducted by Bispo, Soares, and Cavalcante (2014), without, however, focusing on organizational learning. In this way, the objective of this work is to analyze the national scientific production on organizational learning that used the practice-based studies approach. To that end, the following specific objectives were outlined: 1 . to present the scientific production evolution on the theme; 2 . to identify the authorship profile and cooperation between authors; 3 . to describe the productions' methodological characteristics; and 4. to investigate related issues.

The research covered the papers available in the Scientific Periodicals Electronic Library (Spell) database, and the Capes Journals Portal, published until 2017. A systematic review of the texts was implemented to carefully analyze the scientific production characteristics, and, thus, to contextualize the research on learning in the PBS approach, drawing attention to how it is being developed in the Brazilian context.

Given that studies that review the national scientific production on organizational learning in the PBS context have not been identified, the potential contributions of this work are strengthened by exploring and presenting the characteristics of this field of convergence between the two areas, through publications analysis.

\section{ORGANIZATIONAL LEARNING AND ITS PERSPECTIVES}

Organizational learning became widely recognized in the 1990s. It is characterized by a multiparadigmatic field, given the diversity of theoretical and methodological approaches that surround it (Antonello \& Godoy, 2010; Bispo \& Godoy, 2012; Easterby-Smith \& Araujo, 2001). To exemplify such diversity, Easterby-Smith's (1997) seminal study - one of the first efforts to classify the theme - was used. The author gathers contributions in six academic perspectives, based on the ontological assumptions present in each of them: psychology, management science, organization theory, strategy, production management, and cultural anthropology. A brief description of 
each perspective, with some adaptations made by Bispo and Godoy (2012), is presented in Figure 2.1.

\section{(Figure 2.1)}

\section{PERSPECTIVES OF ORGANIZATIONAL LEARNING}

\begin{tabular}{ll}
\hline \multicolumn{1}{c}{ Perspective } & \multicolumn{1}{c}{ Description } \\
\hline Psychology Perspective & $\begin{array}{l}\text { It focuses on human development in the organizational context, } \\
\text { proposing the existence of different levels or stages when it comes } \\
\text { to individual learning, which is influenced by the environment and } \\
\text { organizational experiences, and involves the interrelationship } \\
\text { between thought and action. }\end{array}$ \\
\hline Management science & $\begin{array}{l}\text { It focuses on the acquisition and processing of information in } \\
\text { the organization, with special emphasis on the creation and } \\
\text { dissemination of knowledge at the organizational level. }\end{array}$ \\
\hline Strategic Perspective & $\begin{array}{l}\text { It aims to examine the extent to which learning provides a } \\
\text { competitive advantage to organizations and how organizations } \\
\text { are able to adapt to the constant changes promoted by the } \\
\text { organizations themselves and the environment in which they are } \\
\text { embedded. }\end{array}$ \\
\hline Production management & $\begin{array}{l}\text { Emphasis on the relationship between learning and organizational } \\
\text { efficiency in terms of productivity. }\end{array}$ \\
\hline Cultural Perspective & $\begin{array}{l}\text { It studies how culture - in its national and organizational } \\
\text { manifestations - influences the processes and the very nature } \\
\text { of learning. }\end{array}$ \\
\hline Sociological Perspective & $\begin{array}{l}\text { It seeks to understand how social systems and organizational } \\
\text { structures affect the learning that takes place within organizations, } \\
\text { drawing attention to aspects related to power, politics and conflicts } \\
\text { that are part of the organizational reality. }\end{array}$ \\
\hline
\end{tabular}

Source: Bispo and Godoy (2012, p. 688).

In a later study, Easterby-Smith and Araújo (2001) explain that, in short, organizational learning studies followed two paths: learning as either a technical or a social process. In the technical view, organizational learning focuses on the processing and interpretation of internal and external information to produce change. For the authors, Huber (1991, p. 89) elucidates this perspective: "An entity learns if, through its processing of information, the range of its potential behaviors is changed". The term technical process is modified for learning as a result/product in the following 
review by Easterby-Smith and Lyles (2005) - a nomenclature that has been adopted by other authors since then.

The technical path is dominant and observable in the perspectives in Figure 2.1, especially in the perspectives of administrative, strategic and production sciences. Thus, behavioral and cognitive theories that aim at organizational efficiency, productivity, the development of competitive strategies, and behavior change to adapt to the environment have been developed. In other words, utilitarian thinking, typical of the functionalist paradigm, predominates.

The review of the Brazilian production on organizational learning, conducted by Antonello and Godoy (2009), confirms that it is predominantly supported by models derived from Psychology and Management Science, with a strong influence on the economic strand. According to the authors, the theoretical models are based on experiential learning and cycles, learning curves, and mental models, which prioritize more behavioral approaches aimed at performance improvement. Consequently, "learning is treated as a technical and cognitive phenomenon, source of competitive advantage, and as a result" (Antonello \& Godoy, 2009, p. 276).

The path that conceives organizational learning as a social process focuses on the meaning that people attribute to their work experiences. "Learning is something that emerges from social interactions, usually in the natural work environment" (Easterby-Smith \& Araujo, 2001, p. 19), so it involves established practices and socialization in community of practices. In this perspective, there is the notion of learning as a social construction, a political process, and a cultural artifact.

The social perspective is treated as an alternative to the dominant one, and it is considered a trend in the theme's evolution. Bertolin, Zwick and Brito (2013, p. 493) argue that the sociological perspective stands out as a "counterpoint to the traditional cognitive view by considering the learning process as a phenomenon incorporated into everyday life, and it is, therefore, the fruit of social interactions.".

As the cut here proposed is that of sociology, from this point, emphasis will be placed on this perspective.

\subsection{Organizational learning in the sociological perspective and practice-based studies}

The sociological perspective of organizational learning is discussed by Gherardi and Nicolini (2001), through the establishment of narratives, 
based on four sociological traditions identified by Collins (1994). To those four, Gherardi and Nicolini (2001) add postmodernism, justifying that, although it is not considered a tradition, it has based the reflection on knowledge and organizational learning as a discursive practice. The narratives are presented in Figure 2.1.1.

\section{(Figure 2.1.1)}

\section{NARRATIVES OF ORGANIZACIONAL LEARNING}

\begin{tabular}{|c|c|}
\hline Sociological tradition & Narratives of Organizational Learning (OL) \\
\hline $\begin{array}{l}\text { Tradition of Conflict } \\
\text { (Marx, Engels, Weber) }\end{array}$ & $\begin{array}{l}\text { - OL as the ideology of a power group; } \\
\text { - OL as a policy of mobilizing resources of power and conflict; } \\
\text { - OL as an attempt to manage the tension between substantial and } \\
\text { formal rationality. }\end{array}$ \\
\hline $\begin{array}{l}\text { Rational-Utilitarian } \\
\text { (Homans, Blau, Cook, } \\
\text { Simon) }\end{array}$ & $\begin{array}{l}\text { - OL as a problem-driven search when organization's performance } \\
\text { does not meet the aspiration levels; } \\
\text { - OL as the activation of an exchange network; } \\
\text { - OL as an ecology of learning located within distributed, multifactor } \\
\text { routines, rather than within individual minds. }\end{array}$ \\
\hline $\begin{array}{l}\text { Durkheinian } \\
\text { (Durkheim) }\end{array}$ & $\begin{array}{l}\text { - OL as a dependent variable. Other variables (strategy, structure, } \\
\text { or culture) define the conditions that facilitate or hinder } \\
\text { organizational learning. Learning is conceived as of one of the } \\
\text { functions of the organizational system, which engenders change } \\
\text { on some occasions and conservation on others; } \\
\text { - OL as socialization to specific cultural codes. Socialization, in fact, } \\
\text { sensitizes subjects to the different orders of society because it } \\
\text { acts selectively on their life-changes, creating a sense of a given } \\
\text { social order's inevitability and restricting the amount of change } \\
\text { that is permitted. }\end{array}$ \\
\hline $\begin{array}{l}\text { Microinteractionist } \\
\text { (Peirce, Mead, Husserl, } \\
\text { Schutz e Garfinkel) }\end{array}$ & $\begin{array}{l}\text { - OL as the transmission of knowledge within the occupational } \\
\text { communities; } \\
\text { - OL as a label that produces a socially constructed reality and that is } \\
\text { produced by this reality. }\end{array}$ \\
\hline Postmodern & - OL as a discursive practice. \\
\hline
\end{tabular}

Source: Adapted from Gherardi and Nicolini (2001).

These narratives show that even the sociological perspective conceives organizational learning differently. The Durkheinian tradition is more functionalistic, whereas the rational-utilitarian one is more structuralist. The tradition of conflicts has a more critical stance and the micro-interactionist and postmodern traditions are more constructivist and interpretivist (Bispo, 2013). 
Nevertheless, the central aspect of the sociological perspective, regardless the epistemological position, is that learning occurs in the individuals' social relations while participating in a society, that is, during interaction (Gherardi \& Nicolini, 2001). Differently from other perspectives, sociology does not assume that learning occurs in people's minds, but "suggests that learning is integrated into the everyday life of individuals. It also suggests that much of the learning comes from the informal source of social relations, which later introduces the concept of practice" (Antonello \& Godoy, 2010, p. 315). In this manner, learning goes beyond information processing and change in the cognitive structure to the idea of participation and integration process (Bispo, 2013).

Because of that, choosing a sociological perspective on learning implies explaining the nature of the social engagements that promote the context for learning. The learning process is related to social knowledge (Gherardi \& Nicolini, 2001), a context that recovers history, language, and materiality as mediators. So, it is a perspective that looks at the locus of social practices, where production, reproduction and transformation of knowledge happen.

The term "practice" is widely used in the academic world by several areas of knowledge and it refers to several phenomena, hence the necessity to clarify how it is used in this research. According to Davel (2014), the Brazilian production on organizational learning, from a sociological perspective, is based on Gherardi and his collaborators' epistemology of practice. This author adopts practice as a unit of analysis and epistemological construction of what she calls practice-based studies or practice-based learning. It is, therefore, "a system of activities in which knowing is not separate from doing and situations might be said to coproduce knowledge through activity" (Gherardi \& Nicolini, 2001, p. 49).

Gherardi (2006, p. 34) defines practice "as a mode, relatively stable in time and socially recognized, of ordering heterogeneous items into a coherent set." In a complementary way, the author presents four characteristics to understand the term: 1 . how a group of activities acquires meaning and becomes recognized as a unit, having as focus the set that the activities assume within a situated action context; 2 . the time in which this situated action is maintained; 3 . the condition of being socially recognized; and 4. A form of society organization.

In this study, Gherardi's (2000, 2001, 2006, 2012) practice-based proposition of organizational learning is adopted. That being so, approaching practice-based learning is to seek the process of building knowledge generated in the social environment, in its everyday realization, and in social practices. And, as a process, it is necessary to understand the dynamics of 
this construction, the relations and mediations that emerge, the negotiation to materialize forms of learning, and the knowledge that reproduces or transforms a social reality. It is with this perspective that practices inserted in the context of the organizations have to be understood as locus of learning study.

\section{METHODOLOGICAL PROCEDURES}

This research is predominantly qualitative and descriptive (Gray, 2012). With respect to the procedures, the research is documental, carried out through the systematic review of the scientific production about the proposed theme. According to Noronha and Ferreira (2000, p. 191), review works analyze the

[...] bibliographic production in a certain thematic area, within a time cut, providing a general overview or a state-of-the-art report on a specific topic, bringing about new ideas, methods, and subtopics that have received more or less emphasis in the specialized literature.

These aspects are also mentioned by De-La-Torre-Ugarte-Guanilo, Takahashi and Bertolozzi (2011, p. 1261), when they assert that it is "a rigorous methodology proposed to: identify the studies on one specific theme, applying explicit and systematic search methods; evaluate the quality and validity of those studies, as well as the applicability". Thus, systematic review offers benefits to the field of study, in particular, it provides an understanding of the course of research in certain areas.

Data collection was conducted in public consultation databases; in the Spell repository, since it is a system of indexing, search and free availability of scientific production of the main national journals of Public Administration and Business, Accounting and Tourism. Capes Journal Portal was also used, because it is more comprehensive, with a large collection of titles and reference bases.

To perform the search, it was intended to obtain all publications relating to organizational learning that used the practice-based approach, regardless the year of the publication. To determine the search strategies, several tests were executed aiming at the most comprehensive result possible. Several terms, considered synonyms by the literature, were tested. Finally, advanced search was chosen, and only the term "learning", in the document title, and the terms "organizational learning" and "practice", in the document's abstract (Spell database) and in any part of the text (Capes Portal) were used. 
In this format, as a result, 31 papers were obtained in Spell and 346 peer-reviewed papers in the Capes Portal, totaling 377. The results of both databases included the title, authors, journals in which it was published, year of publication, abstract, keywords and the link to get the full text. With this information and, when necessary, with the full text, the first analysis was made, identifying whether each of the papers met the proposal of this study to discuss organizational learning in practice-based studies approach, discarding those that did not contemplate this theme approach. To assist in the process, two questions were asked:

- Is the study about organizational learning?

- Is practice discussed in the context of practice-based studies?

To be retained, the paper would need to receive an affirmative answer to both questions. At this stage, repeated texts were also discarded from one of the databases. After this analysis, 42 papers remained in the study.

The exclusion occurred because Capes Journals Portal covers journals from all areas of knowledge, and since the term "learning" (the only search criterion in the document title) is used in several areas of knowledge, many papers in the area of Education appeared in the 346 results. Moreover, the term "practice", used as a filter, is also a term used in many areas of knowledge and it represents different phenomena, so the term's use often did not correspond to the practice-based approach proposed in this study. Figure 3.1 presents an overview of the data collection stages.

\section{(Figure 3.1)}

\section{STAGES OF DATA COLLECTION}

Search strategies
Document type
Paper
Publication period
Start: without definition
End: 2017
Search date
April 30,2018

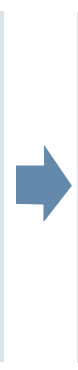

Spell Base
Search terms
In the title:
- learning
In the abstract:
- organizational learning and
- practice
Results: 31 papers
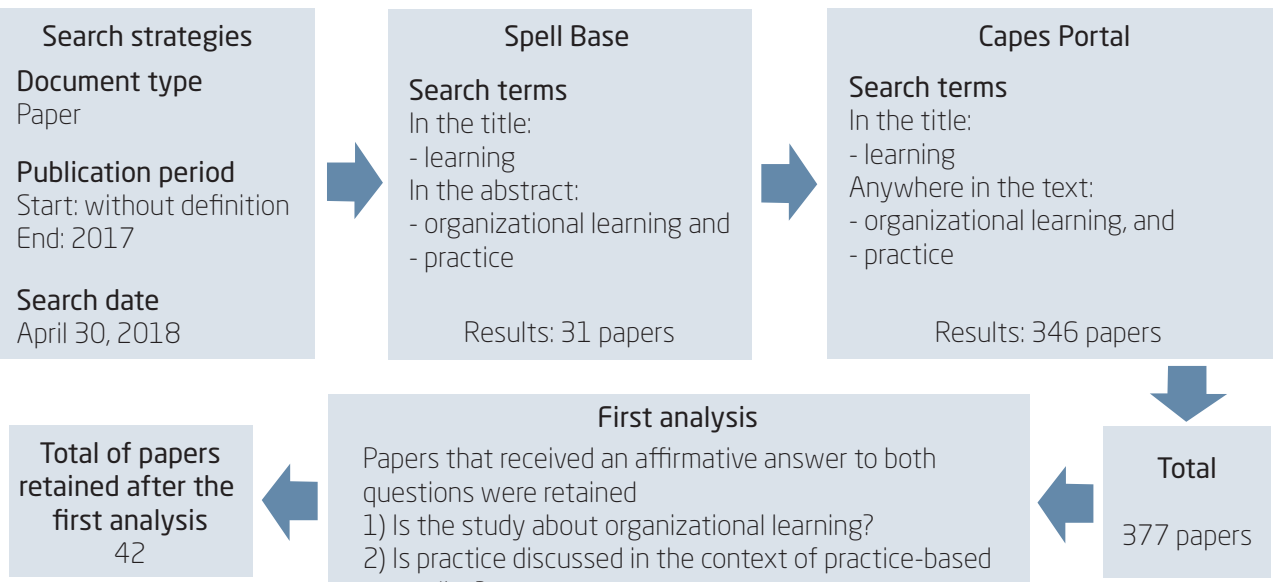

\section{First analysis}

Papers that received an affirmative answer to both questions were retained

1) Is the study about organizational learning?

2) Is practice discussed in the context of practice-based studies?

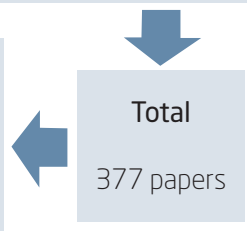

Source: Elaborated by the authors. 
Then, the second analysis was performed. In this stage, the full texts of the 42 papers were (re)analyzed for information gathering based on the specific objectives: title, journal, year of publication, authorship, affiliation and title of the authors, objective of the study, keywords, thematic correlates and methodological characteristics. In some cases, the author's lattes curriculum was also used to obtain complementary information such as affiliation and title. Capes Sucupira Platform was also used to gather more information about the journals. A worksheet was created in Microsoft Excel to systematize this information, which is presented in the form of charts, tables or graphs in the following section.

In the case of data analysis, with the systematic review of papers, it was possible to identify the number of papers published per year and the journals that published them, elucidating the production evolution. The authorship profile was verified in relation to the number of authors by text, the affiliation and title of the authors, the authors who published more on the subject and the cooperation between authors. In this case of cooperation, Ucinet 6 and NetDraw software were used.

As for the methodological characteristics, the typology was verified as regards the nature, researches approach and the methodological procedures. Data collection and analysis techniques were also verified. Finally, the related themes discussed in the papers were analyzed.

\section{PRESENTATION AND RESULTS ANALYSIS}

Although the subject of organizational learning is widely explored, researches using practice-based studies approach, a postmodern narrative, are recent. The first Brazilian publication found dates back to 2005. Figure 4.1 shows the number of productions per year, illustrating the evolution of researches on the theme: 


\section{(Figure 4.1)}

\section{EVOLUTION OF THE QUANTITY OF PAPERS THROUGHOUT THE YEARS}

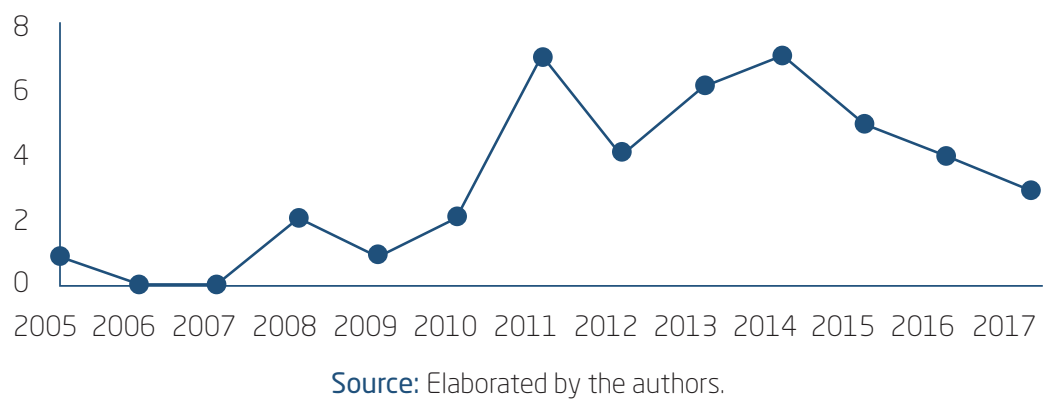

The annual quantity cannot be considered large, but a relevant aspect is that since 2008 publications have occurred in every year, and as of 2011 their number has remained above four, what indicates a new approach to the theme and its development in the Brazilian context. On the other hand, there is a tendency for productions to fall after 2014. The fact that few studies adopt some of the sociological perspectives of learning has already been pointed out in other studies, such as Bispo and Mello (2012).

To verify the production evolution, it was also considered relevant to know the journals in which the 42 papers on the subject were published. Figure 4.2 presents this information. The classification information corresponds to the area of Public Administration and Business, Accounting, and Tourism, quadrennium of 2013-2016, available on Sucupira platform.

\section{(Figure 4.2)}

JOURNALS IN WHICH PAPERS WERE PUBLISHED

\begin{tabular}{lcccc}
\hline \multicolumn{1}{c}{ Journal } & ISSN & Qualis & Number \\
\hline Mackenzie Administration Journal & $1678-6971$ & $\mathrm{~B} 1$ & 6 \\
\hline Public Administration Journal & $0034-7612$ & $\mathrm{~A} 2$ & 4 \\
\hline Journal of Contemporary Management & $1415-6555$ & $\mathrm{~A} 2$ & 3 \\
\hline Cadernos EBAPE.BR & $1679-3951$ & $\mathrm{~A} 2$ & 3 \\
\hline Management Theory and Practice & $2238-104 \times$ & $\mathrm{B} 2$ & 2 \\
\hline Electronic Journal of Administration & $1413-2311$ & $\mathrm{~B} 1$ & 2 \\
\hline Management in Dialogue Review & $2178-0080$ & $\mathrm{~B} 3$ & 2 \\
\hline
\end{tabular}




\section{(Figure 4.2 (conclusion))}

JOURNALS IN WHICH PAPERS WERE PUBLISHED

\begin{tabular}{lccc}
\hline \multicolumn{1}{c}{ Journal } & ISSN & Qualis & Number \\
\hline Alcance & $1413-2591$ & B2 & 2 \\
\hline Brazilian Business Review & $1808-2386$ & $\mathrm{~A} 2$ & 1 \\
\hline Organizations \& Society & $1413-585 X$ & $\mathrm{~A} 2$ & 1 \\
\hline Journal of Business Management & $2178-938 X$ & $\mathrm{~A} 2$ & 1 \\
\hline Public Administration and Social Management & $2175-5787$ & $\mathrm{~B} 1$ & 1 \\
\hline Management \& Production & $1806-9649$ & $\mathrm{~B} 1$ & 1 \\
\hline Perspectives on Information Science & $1981-5344 \mathrm{~b}$ & $\mathrm{~B} 1$ & 1 \\
\hline Journal of Entrepreneurship and Small Business Management & $2316-2058$ & $\mathrm{~B} 1$ & 1 \\
\hline Management Journal & $2177-8736$ & $\mathrm{~B} 1$ & 1 \\
\hline FACES Journal & $1984-6975$ & $\mathrm{~B} 2$ & 1 \\
\hline Management \& Planning & $2178-8030$ & $\mathrm{~B} 2$ & 1 \\
\hline HoLOS & $1807-1600$ & $\mathrm{~B} 2$ & 1 \\
\hline Contemporary Thinking in Management Journal & $1982-2596$ & $\mathrm{~B} 2$ & 1 \\
\hline Organizations in Context Journal & $1982-8756$ & $\mathrm{~B} 2$ & 1 \\
\hline Perspectives in Management \& Knowledge & $2236-417 X$ & $\mathrm{~B} 3$ & 1 \\
\hline Brazilian Journal of Management and Innovation & $2319-0639 \mathrm{~b}$ & $\mathrm{~B} 3$ & 1 \\
\hline Journal of Administration, Accounting and Economics & $2179-4936$ & $\mathrm{~B} 3$ & 1 \\
\hline Interdisciplinary Journal of Social Management & $2317-2428$ & $\mathrm{~B} 4$ & 1 \\
\hline Free Text: Language and Technology & $1983-3652$ & - & 1 \\
\hline & & Total & 42 \\
\hline
\end{tabular}

Source: Elaborated by the authors.

The papers were published in 26 different Brazilian journals, highlighting the RAM, RAP, RAC and Cadernos EBAPE.BR, which published the most. In general, the papers were published in Brazilian journals of reference, of which quality and national and international impact are attested by Qualis system of Capes, since more than $80 \%$ of the production is in A2 (13 papers), B1 (13 papers) and B2 (9 papers) journals. Only one paper was published in an unclassified journal in the area of Public Administration and Business, 
Accounting, and Tourism, but this journal is classified in other areas of knowledge, such as Interdisciplinary, with B2 level.

\subsection{Author profile}

The authorship of the 42 texts is under the responsibility of 69 different authors. The great majority of the production is accomplished in partnership between authors, since only six papers are of individual authorship. The partnership between two authors predominates, with almost $60 \%$ of production. As for the authors' title, the great majority had, at the time of publication, a doctorate degree.

From the 69 authors, 13 participate in more than one publication and the other 56 in a single publication. Among the authors, three are distinguished by the number of publications, which motivated to know their history based on the Lattes curriculum. Claudia Simone Antonello (eight productions) is a $\mathrm{PhD}$. in Administration, a professor of the stricto sensu Post-Graduation Program in Administration at UFRGS and she holds a CNPq research productivity scholarship. She has a history of national and international publication about learning in organizations, and among her research themes are the practices and learning in organizations $(\mathrm{CNPq}$, 2018). Arilda Schmidt Godoy (five productions) is a PhD. in Education and she was a professor in the Graduate Program in Business Administration at Mackenzie Presbyterian University. In the last years, her academic production was focused in the areas of education and administration (CNPq, 2018). Finally, Marcelo de Souza Bispo (five productions) holds a doctorate in Administration, and he is a professor of the stricto sensu Post-Graduation Program in Administration at UFPB. Among his subjects of interest are the studies based on practice, and learning and knowledge (CNPq, 2018). The three professors hold research projects on organizational learning and practice theories (CNPq, 2018).

A relevant analysis is the cooperation established in conducting the research, as it demonstrates the effort in disseminating the approach. Figure 4.1.1 shows the 69 authors, and the size of the circle illustrates the centrality that the author occupies in the network, while the thickness of the line represents the strength of the relation. 


\section{(Figure 4.1.1) \\ COOPERATION NETWORKS BETWEEN AUTHORS FROM UCINET6 AND NETDRAW}

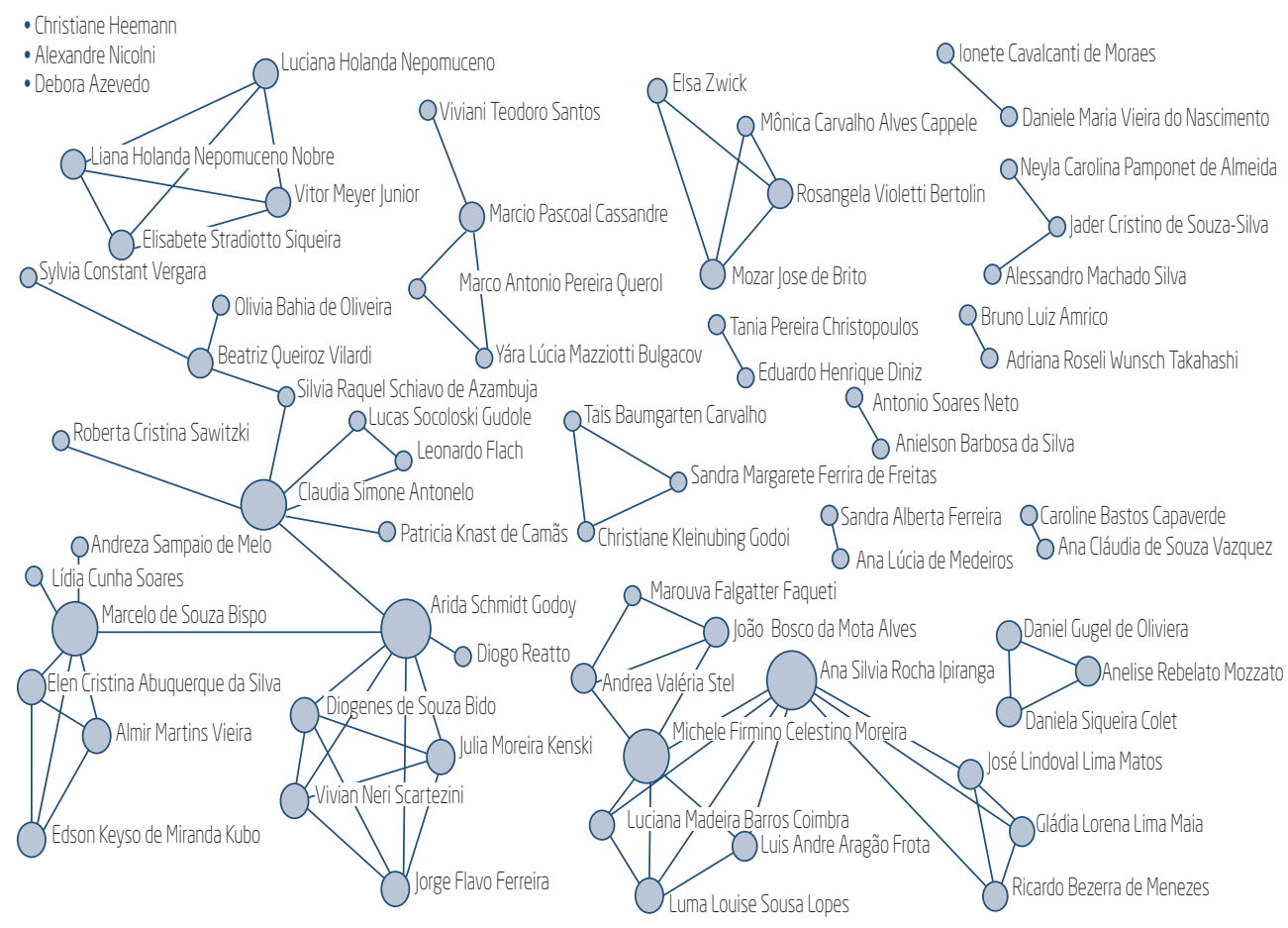

Source: Elaborated by the authors.

It is possible to identify the formation of some networks and the articulating role that some authors play in their formation. There is a larger network formed by 21 authors and articulated by the three researchers with more publications (Antonello, Godoy, and Bispo). In this network, Godoy (Mackenzie Professor) stands out by uniting the other two groups, hence playing a central role. The second largest group consists of 11 authors articulated especially by Ipiranga (UECE). As for the relations strength, the great majority is relative to one publication. The strongest relation occurs between Antonello and Flach (3 productions), followed by Antonello and Godoy (2), Brito and Bertolin (2), Souza-Silva e Almeida (2), and Américo and Takahashi (2).

Also related to the authorship of the texts is the authors' affiliation. In this respect, the 42 texts were developed within the scope of 27 Higher Education Institutes (HEIs), with a concentration around four: Federal 
University of Rio Grande do Sul (UFRGS), Federal University of Paraíba (UFPB), Federal University of Santa Catarina (UFSC), and Mackenzie Presbyterian University, which together account for almost $50 \%$ of the production. This concentration can be explained by the fact that the authors who have more publications are linked with these HEIs. Another situation is that of the 27 HEIs, 16 have a single published text. The 27 HEIs cover, geographically, the five regions of the country, which is relevant for the dissemination and strengthening of the theme at the national level.

\subsection{Methodological characteristics}

Concerning the nature of the research, of the 42 papers, 15 are theoretical and 27 theoretical-empirical. As for the research approach, 40 papers are qualitative, one is quantitative and one is mixed, to wit: almost the entire production adopted qualitative research. This approach is justified because in the studies on social practices the concern is to deepen the understanding of a social reality situated and constituted in a unique and distinct way and for that reason can be researched (Goldenberg, 2009). In this direction, they follow the positions of Gherardi (2012) and Nicolini (2013), among others, that advise that the studies on practices are essentially qualitative. In this manner, it was identified that Brazilian production is consistent with this practice-based studies methodological assumption.

Regarding the methodological procedure adopted (Figure 4.2.1), the predominance of the case study is observed, which is close to the situated practices studies perspective, provided that the analytical cut is the practice and its context of constitution. In foreign literature, ethnographic methods and grounded theory are prioritized, precisely because these strategies make it possible to research practices in the social context (Bispo \& Soares; Cavalvante, 2014; Gherardi, 2012). From the sociological point of view, empirical studies can also use analyzes that recover the historical and procedural character of practices, through life history, oral history and hermeneutics. 


\begin{tabular}{|c|c|c|c|}
\hline \multicolumn{4}{|c|}{ METHODOLOGICAL PROCEDURE } \\
\hline Theoretical studies & Number & Theoretical-empirical studies & Number \\
\hline Theoretical work & 8 & Case study & 13 \\
\hline \multirow[t]{6}{*}{ Bibliographic research } & 7 & Field research & 7 \\
\hline & & Production Review & 3 \\
\hline & & Hermeneutics & 1 \\
\hline & & Life history & 1 \\
\hline & & Oral history & 1 \\
\hline & & Interpretive survey & 1 \\
\hline Total & 15 & Total & 27 \\
\hline
\end{tabular}

Source: Elaborated by the authors.

Another focal point is the bibliographical research and theoretical essays, which together with the production reviews totaled 18 works $(34.6 \%)$. This shows the recent character of the research developed in the context of learning and social practices, since they portray a concern that supports the beginning of larger studies, in other words, before developing an empirical study, they seek to understand the theories that underlie the works and the directions of the studies.

With regard to the collection of empirical data (Figure 4.2.2), a total of 26 papers, the techniques used, most of the times, sought to establish relations between researcher and subjects and to capture information and meanings, characteristic of qualitative studies. The predominant technique was the interview, but, in general, more than one technique was used, one complementing the other, such as interview, observation and documentary analysis.

\section{(Figure 4.2.2)}

TECHNIQUES FOR EMPIRICAL DATA COLLECTION AND ANALYSIS

\begin{tabular}{lclc}
\hline $\begin{array}{c}\text { Empirical data } \\
\text { collection technique }\end{array}$ & Number & $\begin{array}{c}\text { Empirical data } \\
\text { analysis technique }\end{array}$ & Number \\
\hline Interview & 23 & Interpretive analysis & 6 \\
\hline Observation & 13 & Content analysis & 5 \\
\hline
\end{tabular}


(Figure 4.2 .2 (conclusion))

TECHNIQUES FOR EMPIRICAL DATA COLLECTION AND ANALYSIS

\begin{tabular}{lclc}
\hline $\begin{array}{c}\text { Empirical data } \\
\text { collection technique }\end{array}$ & Number & \multicolumn{1}{c}{$\begin{array}{c}\text { Empirical data } \\
\text { analysis technique }\end{array}$} & Number \\
\hline Documentary & 9 & Speech analysis & 3 \\
\hline Informal conversation & 2 & Interpretive and dialectical analysis & 2 \\
\hline Field diary & 2 & Descriptive and factorial statistics & 2 \\
\hline Focus Group & 2 & Systematic review & 3 \\
\hline Bibliometric Inspiration & 3 & Triangulation & 2 \\
\hline Questionnaire & 2 & Narrative analysis and conversation & 1 \\
\hline Testimony & 1 & Grounded theory & 1 \\
\hline Confrontation method & 1 & Phenomenological inspiration & 1 \\
\hline & & Total & 26 \\
\hline
\end{tabular}

As the orientation for research on social practices is the development of an ethnographic study and this is characterized by the use of the participant observation technique (Cavedon, 2014), the use of this technique was identified in 13 of the 26 empirical studies, and systematic observation was more common than the participant one observation. Gherardi (2012) recommends participant observation of practical activities as a way of "living" the situated reality and especially of perceiving the relations and actors that constitute the practice, as well as the knowledge and processes of transmission of know-how. In this way, this shortcoming is identified in the Brazilian scientific production.

In respect to the techniques employed to analyze the empirical data (Figure 4.2.2), different qualitative research techniques were adopted, prioritizing the interpretation of meanings. Descriptive statistics were used in two papers that applied the quantitative approach. Besides, it was observed the use of analysis whose units of analysis were not the actual practices, but organizations or subjects. In this sense, the positioning of Reckwitz (2002), Gherardi (2012), Nicolini (2013), and Gherardi and Strati (2014) are similar vis-à-vis the fundamentals of this analytical perspective, which defines practice as a unit of analysis, a place where the social is manifested and constituted. They justify that choosing practice as a locus to study phenomena such as learning makes it possible to reach a more assertive and comprehensive 
view on how the learning process occurs in the everyday life situated in social reality.

\subsection{Related themes}

The studies, in general, use the learning and call attention to relevant themes to the PBS theoretical-methodological proposal. From these themes, they broadly discuss the PBS theoretical perspective. Azevedo (2013) clarifies one of the main assumptions that sustain the PBS, the practice as epistemology. This work draws on several works on PBS, especially to the researcher Silvia Gherardi's proposal, which resumes the practice definition construction as a locus of social realization and generation of a social order that guides practitioners in social life (Gherardi, 2002). This paper is essential for researchers who wish to approach the practice as it was thought in the PBS, without running the risk of viewing practice as a deterministic or functionalist mechanism. Besides this study, all bibliographic works and the theoretical essays were relevant in their contributions, since each one extended debates on the learning studies characterization or some themes relevant to the PBS.

The most cited and discussed theme in several studies is community of practice as the focus of analysis of the categories explained by Lave and Wenger (1991), and also presented by Nicolini and Gherardi (2001). These works seek to understand how learning occurs in communities of practice, based on sociological assumptions.

A theme that is part of the scope of the PBS corresponds to the experience that puts in discussion the subject's action in the everyday situated practices. In this context, the PBS proposal presupposes a subject who learns not only in doing. This implies discussing the philosophical bases on the action potential of the subject and all the process mediating dimensions. In consequence, it is necessary to analyze intentionality, aesthetics, relations of power, materiality, historicity and any other aspects that contribute to guide the subject to act. In this regard, the historical subject's experience that triggers reflection and consciousness in the ordinary, passive or active way are important discussions to the PBS, and some works have begun discussions in this direction.

Aesthetics and corporeity are also emphasized as dimensions that intertwine the affective and social categories in the construction of practical knowledge, which leads to ethical and aesthetic judgments that guide the subject in the everyday social practice. In this way, they compose a 
relevant analytical category to understand how learning is constituted in the PBS context.

Improvisation emerges as a relevant dimension to the study of the situated and everyday context of practical-based learning, making analogy with the practice of the musicians in the Choro performance as a musical rhythm that demands knowledge, but that is developed based on constant improvisations in its execution.

Other theories that relate to the theories that gave origin to some assumptions of PBS are seen in networks studies, multi-actor perspective and activity theory. These papers also draw on some PBS assumptions, but some studies are also based on positivist empirical analysis, with a deterministic orientation on what practitioners should learn to succeed in their practice or on the practitioners' stages and levels of learning.

On the other hand, focus is given to Américo's study (2016), which contributes with a coherent analysis on the activity theory influence that is extended by him from a dialogue between the social-political perspective of social learning, actor-network theory and Foucaultian studies. The work of Querol, Cassandre, and Bulgacov (2014) extends the understanding of the Activity Theory as a strong strand of PBS, showing the directions that this strand takes to constitute an analytical and theoretical perspective of learning from social practices. One of the contributions of this paper is the study of Russian tradition theorists who theorize expansive learning from the historical-cultural perspective linked to dialectical materialism, expanding explanations about the subject-object relation in the constitution of knowledge that is taught in the context of human activities, viz., it is embodied in cultural artifacts.

Similarly, Americo and Takahashi (2014), and Capaverde and Vazquez (2015) deal with power relations as the mediating dimension of practical knowledge construction that generates a situated learning mode reproduces or challenges social knowledge. These authors reach a certain postmodernist tone in their analyzes when they present a critical look to analyze the different voices that constitute practical organization dynamics. This critical sensitivity also composes the set of PBS constructivist assumptions (Biscoli, 2017).

In the postmodern direction, it is also possible to spotlight the contribution of Christopoulos and Diniz (2008) that relate learning to the context of identity construction, using the actor-network theory as a reference. This study also stresses the use of Grounded Theory as a methodology. In the postmodern approach, there is also techno-science, in which the authors clarify how the relation between the material and social dimensions constitute the learning context. 
Finally, the contribution of the empirical studies is highlighted, exemplifying the use of methodologies and analytical relations capable of explaining learning from the PBS perspective, which discuss the themes of manager training, safety culture, and cleaners, cooks, and administrative technicians' learning. Furthermore, there are the studies that exemplify methodological strategies, such as metatriangulation and ethnomethodology, which broaden the understanding of PBS assumptions and develop a methodology of learning analysis through situated practices.

\section{FINAL CONSIDERATIONS}

The scientific production on organizational learning, which used the practice-based studies approach, was reviewed to portray the Brazilian publications context. For the interest of this work, the conception of learning in the sociological perspective was adopted, specifically that which takes the learning as a process built in the everyday social relations, with the mediation of multiple mediations, from Silvia Gherardi's practice of epistemology. As a result, social practices reveal themselves as contexts of social organization that generate knowledge and learning.

The first specific objective consisted of verifying the evolution of publications. In this respect, it was verified that organizational learning in the PBS approach is a recent discussion in the world, and, in Brazil, publications began to emerge in the early 2000s. Although there is not a high number of papers, they are focused on journals with national and international impact, evidencing that they are in the process of strengthening.

On the one hand, the publications' authorship (second specific objective) is under the responsibility of small groups and they are still dispersed, even by the recent character of the discussions. On the other hand, the great majority of the production is the result of partnerships between authors, with three prominent researchers due to the number of papers published, who represent the Brazilian universities of UFRGS, UFPB, and Mackenzie. These authors are part of the same authorship network and they are disseminators of the theme in the country.

As for the methodological characteristics (third specific objective), it was found that there is a large number of publications that mention the search terms "learning", "organizational learning" and "practice". Even after selecting the works adhering to the theme, several papers were found with more structuralist and positivist epistemological postures, which contradicts 
the basic assumptions of the perspective adopted in this work. For similar reasons, there are also works that tried to establish a relation between the themes, but performed interpretation choosing as units of analysis organizations or subjects and not the practice as proposed by on practicebased studies.

It should be emphasized that the case study can be used as a methodological proposal in the empirical studies of PBS, but the analytical cut should turn to social practices and their context of constitution. Consequently, it is considered that the Brazilian studies still need improvement and debate to constitute a body of publications that meet the assumptions intended by the PBS idealizers. Conversely, among the works analyzed, there are also some that are guided by assumptions consistent with PBS, both in the themes and in the construction of empirical research designs.

It is possible to mention the significant number of papers that developed theoretical analyzes and the relevance of their contributions, since each of them broadened debates about the characterization of the learning studies or of some themes relevant to the PBS. This demonstrates that there is still much to grasp about the philosophical underpinnings of PBS theorizations, and Brazilian researchers have gradually devoted themselves to this quest, although the number of publications has fallen after 2014. This data alone, however, does not mean reduction of commitment or publications, because it is possible that the Brazilian researchers are resorting to international events and journals, where the theme is already more developed.

More specifically on the related themes (fourth specific objective), it was verified that great part of the studies was dedicated to clarify the theoretical aspects of learning in the relation between several themes of interest. The theme of organizational learning was recurrent, maintaining relations with most of the other themes, which were inserted, most of the time, in the PBS context. Discussions of methodological aspects were also present among the themes.

It is still possible to highlight studies that not only have sought to understand the PBS perspective, but also have begun to develop thematic that contribute by investigating gaps to broaden the theoretical understanding of PBS, as is the case of improvisation analysis as a mediation of the knowledge construction processes in the everyday social practices, and the rescue of power as a dimension little explored in PBS contemporary studies.

Concerning this matter, it can be concluded that the research on learning in the PBS approach has little insertion in the Brazilian context. This may be due to the small number of studies and researchers involved, the lack of 
Brazilian journals that accept this type of publication, or the researchers' choice to publish in international journals. These motivations suggest the execution of other researches, such as the production mapping of Brazilian researchers in international journals.

It is also concluded that organizational learning, discussed in the PBS approach, which takes the practices inserted in the context of organizations as a locus of learning study, presents potential to fill gaps in the technical tradition and in the tradition as a result.

\section{APRENDIZAGEM ORGANIZACIONAL NA ABORDAGEM DOS ESTUDOS BASEADOS EM PRÁTICA: REVISÃO DA PRODUÇÃO CIENTÍFICA}

\section{RESUMO}

Objetivo: Revisar a produção científica sobre aprendizagem organizacional, que utilizou a abordagem dos estudos baseados em prática, no tocante à evolução da produção, ao perfil de autoria, às características metodológicas e às temáticas correlatas.

Originalidade/valor: A aprendizagem organizacional apresenta lacunas quanto a contribuições de outras áreas, como Sociologia. Os Estudos Baseados em Práticas (EBP) têm o viés sociológico e o espaço social como lócus para os processos de aprendizagem e a geração de conhecimento. Não foram identificados estudos que revisem a produção científica nacional em aprendizagem organizacional no contexto dos EBP, reforçando as contribuições potenciais deste trabalho.

Design/metodologia/abordagem: A pesquisa abrangeu os artigos disponíveis na base de dados da Spell e no portal de periódicos da Capes, publicados até 2017, no total de 42. Estes foram revisados sistematicamente e numa abordagem qualitativa. Também foram utilizados os softwares Ucinet6 e NetDraw na análise.

Resultados: As publicações são recentes e concentram-se em periódicos de impacto nacional e internacional. A autoria está sob responsabilidade de pequenos grupos, ficando em evidência a parceria entre autores. É significativa a quantidade de artigos teóricos e a relevância de suas contribuições. Nos estudos empíricos, predomina o estudo de caso e a entrevista. 
Quanto às temáticas, são discutidos temas relevantes à proposta teórico-metodológica dos EBP. Concluiu-se que os EBP, por tomarem as práticas inseridas no contexto das organizações como lócus para o estudo da aprendizagem, revelam potencial para preencher lacunas da perspectiva tradicional da aprendizagem organizacional.

\section{PALAVRAS-CHAVE}

Aprendizagem organizacional. Perspectiva sociológica. Estudos baseados em prática. Revisão sistemática. Epistemologia.

\section{REFERENCES}

Américo, B. L. (2016). Aprendizagem organizacional, teoria ator-rede e estudos Foucaultianos: Tempo, espaço e poder. Revista de Administração FACES Journal, 15(4), 66-78. doi:10.21714/1984-6975FACESOVONOART3532

Américo, B. L., \& Takahashi, A. R. W. (2014). Conhecimento, aprendizagem organizacional e poder na rede: Um estudo de caso na Secretaria de Educação e Cultura de Coahuila, México. Revista Administração Pública, 48(2), 411-437. doi:10.1590/0034-76121323

Antonello, C. S. (2005). A metamorfose da aprendizagem organizacional: Uma revisão crítica. In R. L. Ruas \& C. S. Antonello (Orgs.), Aprendizagem organizacional e competências. Porto Alegre, RS: Bookman.

Antonello, C. S., \& Godoy, A. S. (2010). A encruzilhada da aprendizagem organizacional: Uma visão paradigmática. Revista de Administração Contemporânea, 14(2), 310-332. doi:10.1590/S1415-65552010000200008

Antonello, C. S., \& Godoy, A. S. (2009). Uma agenda brasileira para os estudos em aprendizagem organizacional. Revista de Administração de Empresas, 49(3), 266-281. doi:10.1590/S0034-75902009000300003

Azevedo, D. (2013). Aprendizagem organizacional e epistemologia da prática: Um balanço de percursos e repercussões. Revista Interdisciplinar de Gestão Social-RIGS, 2(1). doi:10.9771/23172428rigs.v2i1.10045

Bertolin, R. V., Zwick, E., \& Brito, M. J. (2013). Aprendizagem organizacional socioprática no serviço público: Um estudo de caso interpretativo. Revista Administração Pública, 47(2), 493-513. 
Biscoli, F. R. V. (2017). A dimensão cultural como construção social incorporada na prática de Secretariado Executivo da Sicredi do oeste paranaense (Doctoral dissertation). Universidade Positivo, Curitiba, PR, Brazil.

Bispo, M. De S., \& Godoy, A. S. (2012). A etnometodologia enquanto caminho teórico-metodológico para a investigação da aprendizagem nas organizações. Revista de Administração Contemporânea, 16(5), 684-704.

Bispo, M. S. (2013). Aprendizagem organizacional baseada no conceito de prática: Contribuições de Silvia Gherardi. Revista de Administração Mackenzie, 14(6), 132-161. doi:10.1590/S1678-69712013000600007

Bispo, M. S., Soares, L. C., \& Cavalcante, E. D. C. (2014). Panorama dos estudos sobre "prática" no Brasil: Uma análise da produção. Anais do Encontro da Associação Nacional de Pós-Graduação e Pesquisa em Administração, Rio de Janeiro, RJ, Brazil.

Bispo, M. S., \& Mello, A. S. (2012). A miopia da aprendizagem coletiva nas organizações: Existe uma lente para elas? Revista Gestão e Planejamento, 12(3), 728-745.

Carrasco, T. S., \& Silva, F. M. (2017). Aprendizagem informal no contexto de trabalho: Um meta-estudo da produção científica brasileira. Revista de Administração Mackenzie, 18(1), 137-163. doi:10.1590/1678-69712017/ administracao.v18n4p137-163

Cavedon, N. R. (2014). A qualidade de vida no trabalho na área da Segurança Pública: Uma perspectiva diacrônica das percepções olfativas e suas implicações na saúde dos servidores. Organizações \& Sociedade, 21 (68), 875-892.

Collins, R. (1994). Four sociological traditions. Oxford, UK: Oxford University Press.

Capaverde, C. B., \& Vazquez, A. C. S. (2015). Implantação de processo eletrônico no sistema judiciário: Um estudo sobre aprendizagem organizacional em uma secretaria de gestão de pessoas. Revista Eletrônica de Administração, 81 (2), 462-490. doi:10.1590/1413-2311.0592014.53649

Christopoulos, T. P., \& Diniz, E. H. (2008). Sustentação das comunidades virtuais de aprendizagem e de prática. Organizações em contexto, 4(8), 74-99. doi:10.15603/1982-8756/roc.v4n8p74-99

Davel, E. (2014). Primeiro momento: Sobre a prática em contexto brasileiro. In S. Gherardi, \& A. Strati (Orgs.), Administração e aprendizagem na prática. Rio de Janeiro, RJ: Elsevier.

De-La-Torre-Ugarte-Guanilo, M. C., Takahashi, R. F., \& Bertolozzi, M. R. (2011). Revisão sistemática: Noções gerais. Revista da Escola de Enfermagem USP, 45(5), 1260-1266. doi:10.1590/S0080-62342011000500033 
Easterby-Smith, M. (1997). Disciplines of organizational learning: Contributions and critiques. Human Relations, 50, 1085-1113. doi:10.1023/ A:1016957817718

Easterby-Smth, M., \& Araujo, L. (2001). Aprendizagem organizacional: Oportunidades e debates atuais. In M. Easterby-Smth, J. Burgoyne, \& L. Araujo (Orgs.), Aprendizagem organizacional e organização de aprendizagem: Desenvolvimento na teoria e na prática. São Paulo, SP: Atlas.

Easterby-Smith, M., \& Lyles, M. (2005). Handbook of organizational learning and knowledge management. Malden, MA: Blackwell.

Faqueti, M. F., Alves, J. B. M., \& Steil, A. V. (2016). Aprendizagem organizacional em bibliotecas acadêmicas: Uma revisão sistemática. Perspectivas em Ciência da Informação, 21 (4), 156-179. doi:10.1590/1981-5344/2699

Gherardi, S. (2012). How to conduct a practice-based study: Problems and methods. Edward. Cheltenham, UK: Elgar. doi:10.4337/9780857933386

Gherardi, S. (2006). Organizational knowledge: The texture of workplace learning. Prometheus, 24(2), 223-232

Gherardi, S. (2001). From organizational learning to practice based knowing. Human Relations, 54(1), 131-139. doi:10.1177/0018726701541016

Gherardi, S. (2000). Practice-based theorizing on learning and knowing in organizations: An introduction. Organization, 7(2), 211-223. doi:10.1177/ 135050840072001

Gherardi, S., \& Nicolini, D. (2001). The sociological foundations of organizational learning. In M. Dierkes et al. (Orgs.), Organizational learning and knowledge. Oxford, UK: Oxford University Press.

Gherardi, S., \& Strati, A. (2014). Administração e aprendizagem na prática. Rio de Janeiro, RJ: Elsevier.

Goldenberg, M. (2009). A arte de pesquisar: Como fazer pesquisa qualitativa em ciências sociais (11a ed.). São Paulo, SP: Record.

Gray, D. E. (2012). Pesquisa no mundo real (2a ed.). Porto Alegre, RS: Penso.

Huber, G. (1991). Organizational learning: The contributing processes and the literature. Organizational Science, 2, 88-115. doi:10.1287/orsc.2.1.88

Lave, J., \& Wenger, E. (1991). Situated learning: Legitimate peripheral participation. New York, NY: Cambridge University Press.

Macedo, M., Botello, L. L. R., Duarte, M. A. T., \& Fialho, F. A. P. (2010). Revisão bibliométrica sobre a produção científica em aprendizagem gerencial. Gestão e Sociedade, 4(8), 619-639. doi:10.21171/ges.v4i8 
Nicolini, D. (2013). Practice theory, work and organization: An introduction. Oxford, UK: Oxford University Press.

Noronha, D., \& Ferreira, S. (2000). Revisões da literatura. In B. S. Campello, B. V. Cendón, \& J. M. Kremer (Eds.), Fontes de informação para pesquisadores e profissionais. Belo Horizonte, MG: Editora da UFMG.

Oliva, C. C., \& Shinyashiki, G. T. (2016). Estudo sobre validação de escalas de aprendizagem organizacional no Brasil. Revista Brasileira de Gestão e Desenvolvimento Regional, 12 (3), 303-322.

Querol, M. A. P., Cassandre, M. P., \& Bulgacov, Y. L. M. (2014). Teoria da atividade: Contribuições conceituais e metodológicas para o estudo da aprendizagem organizacional. Gestão e Produção, 21 (2), 405-416. doi:10.1590/01 04-530X351

Reckwitz, A. (2002). Toward a theory of social practices: A development in culturalist theorizing. European Journal of Social Theory, 5(2), 243-263. doi:10.1177/13684310222225432

\section{AUTHOR NOTES}

Daniela G. Durante, Faculdade de Economia, Administração, Atuária e Contabilidade (FEAAC), Universidade Federal do Ceará (UFC); Fabiana R. Veloso; Departamento de Administração, Universidade Positivo; Diego Q. Machado, Centro de Ciências da Comunicação e Gestão, Universidade de Fortaleza (Unifor); Augusto C. A. Cabral, Faculdade de Ciências Econômicas, Universidade Federal de Minas Gerais (UFMG); Sandra M. Santos, Centro de Ciências Sociais Aplicadas, Universidade Federal de Pernambuco (UFPE).

Daniela G. Durante is now Professor at Faculdade de Economia, Administração, Atuária e Contabilidade (FEAAC) at Universidade Federal do Ceará (UFC); Fabiana R. Veloso is now Professor at Universidade Estadual do Oeste do Paraná (Unioeste); Diego Q. Machado is now Professor at Faculdade de Economia, Administração, Atuária e Contabilidade (FEAAC) at Universidade Federal do Ceará (UFC); Augusto C. A. Cabral is now Director at Faculdade de Economia, Administração, Atuária e Contabilidade (FEAAC) at Universidade Federal do Ceará (UFC); Sandra M. Santos is now Vice Director at Faculdade de Economia, Administração, Atuária e Contabilidade (Feaac) at Universidade Federal do Ceará (UFC).

Correspondence concerning this paper should be addressed to Daniela G. Durante, Rua Marechal Deodoro, 400, Benfica, Fortaleza, Ceará, Brazil, CEP: 60020-060.

E-mail: danielagiareta@gmail.com 


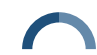

Daniela G. Durante, Fabiana R. Veloso, Diego Q. Machado, Augusto C. A. Cabral, Sandra M. Santos

EDITORIAL BOARD

Editors-in-chief

Janette Brunstein

Silvio Popadiuk

Associated Editor

Silvio Popadiuk

Technical Support

Vitória Batista Santos Silva

\section{EDITORIAL PRODUCTION}

Publishing Coordination Irina Migliari

\author{
Layout Designer \\ Emap
}

\section{Copyeditor}

Irina Migliari (English)

Graphic Designer Libro

Carlos Villarruel (Portuguese)

Language Editor

Daniel de Almeida Leão (English)

Irina Migliari (Portuguese) 